\title{
PRELIMINARY STUDY OF MEAT QUALITY CHARACTERISTICS OF YOUNG N'DAMA AND MUTURU BULLS
}

\author{
*A.G., EZEKWE, **T.M. OKONKWO, *U.G. UKAEGBU AND *A.A. SANGODE \\ *Department of Animal Science, University of Nigeria, Nsukka. \\ **Department of Food Science and Technology, University of Nigeria, Nsukka.
}

Recelved 28 March, 1995; Accepted 28 March, 1997

\begin{abstract}
In order to obtain information on the quality characteristics and acceptability of meat from N'dama (YN) and Muturu (YM) breeds of cattle, the young bulls were slaughtered at about 11 months of age and their Longissimus dorsi (LD) and Psoars major (PM) muscles subjected to chemical evaluation of the raw meat as well as eating quality characteristics of the meat cooked for 10,15 and $20 \mathrm{~min}$. These were compared to meat from mature Sokoto Gudali (SG). Results showed that meat from YM and YN had similar moisture contents but differed significantly $(\mathrm{P}<0.05)$ in fat contents. Meat from YM and YN bulls had higher moisture but lower fat contents compared to meat from SG bulls. The LD muscles had higher \% fat in the three experimental groups than the PM muscles. Total protein and ash contents were similar for all samples but protein solubility was higher $(P<0.05)$ in $Y N$ young bulls compared to mature bulls. YN and YM had similar ultimate pH but these young bulls had lower ultimate pH than mature bulls $(P<0.05)$. Total pigment contents varied $(P<0.05)$ between breeds, maturity and
\end{abstract} muscles types with $Y M$ having higher myoglobin than YN, PM higher than LD and mature bulls more than young bulls. Sensory colour and odour of meat varied $(P<0.05)$ between samples with meat from mature $S G$ bulls being rated lower than those from YM and $Y N$ bulls. After cooking for 10 and 15 min, all samples were acceptable but their tenderness varied between samples, with the young bulls meat being rated as $(P<0.05)$ more tender than mature bulls but on cooking for $20 \mathrm{~min}$, judges could detect significant differences in juiciness, flavour, tenderness and general acceptability of samples.
Generally, meat from young bulls were adjudged more acceptable than meat from mature bulls.

Key Words: Muturu, N'dama, Age, Psoars, Longissimus, Sokoto Gudali

\section{INTRODUCTION}

The relationship between breed, age and muscle type with meat quality characteristics is neither appreciated nor utilized by the meat trader in Nigeria. As a result, little or no effort is made to appropriately inform the meat consumer with regard to eating quality characteristics of meat animals. Experience from many developed countries suggest that rising personal incomes and expanding urban markets promote changes in marketing systems and consumer demands, making it imparative and profitable for the meat industry to cater for those extra requirements. In response, consumers show greater appreciation of quality and variety in meat and meat products. In relation to market changes and consumer demands, livestock farmers in many countries in recent years have tended to produce younger animals because of greater turnover, quick return on investment and the fact that younger animals produce leaner carcasses which are appreciated by present day consumers. Such a shift in consumer preference is obviously not being exploited by livestock producers in Nigeria with the result that juvenile animals are sold for slaughter only in emergency situations.

Two breeds of cattle - Muturu (Bos brachycerus) and N'dama (Bos taurus) - were used in a larger research directed at assessing their total breeding and production potentials. These cattle breeds exist in greater numbers along West African coast where they have developed a high degree of tolerance to trypanosomiasis which ${ }^{-}$is endemic in this 


\section{ET $A L$}

region. Although these breeds are rarely slaughtered in public abattoirs for meat, the Muturu in particular is widely used for socio-cultural activities in the South Eastern State of Nigeria. The present study was therefore aimed at assessing the acceptability of meat from their young bulls when compared to meat from mature and more widely consumed trade cattle in Nigeria - Sokoto Gudali (Bos indicus).

\section{MATERIALS AND METHODS}

\section{Samples Collection and Processing:}

Twelve young Muturu (YM) and 5 young N'dama (YN) bulls were reared at the Department of Animal Science, Univeristy of Nigeria farm and 5 bulls from each group slaughtered at the Department slaughter house at an average age of eleven (11) months. Meat from 5 mature Sokoto Gudali (SG) bulls of about 3 years of age were collected from Nsukka market abattoir and used for comparism. It was not possible to use meat from mature N'dama and Muturu bulls for comparison because of lack of availability. Besides, these breeds are not usually slaughtered in public abattoir for commercial purposes.

Longissimus dorsi (LD) and Psoars major (PM) muslces were collected from each animal immediately after slaughter, trimmed of excess connective tissues and fat and stored frozen until required for analysis. Each muscle was divided into two halves. One half was used for chemical analysis of the raw meat and the remainder was cut into $2 \mathrm{~cm}^{3}$ pieces, sealed in polythene bags and cooked for 10,15 and $20 \mathrm{~min}$. respectivley at boiling temperature. The sensory evaluation of the cooked meat was essential to fully comprehend those factors which affect eating quality because objective assessment of the raw meat does not reliably predict eating quality during organoleptic quality evaluation.

\section{Chemical Evaluation:}

Proximate composition: The chemical proximate composition of the raw meat was determined by AOAC (1990) methods. The $\mathrm{pH}$ was determined on dispersion of $5 \mathrm{~g}$ sample in $50 \mathrm{ml}$ of distilled water using combined glass electrode, after standardizing the $\mathrm{pH}$ meter with PH 4 and 7 buffer solutions.

Nitrogen solubility: Nitrogen solubility study was carried out by homogenising $1.0 \mathrm{~g}$ of the raw meat in $10 \mathrm{ml}$ of $0.1 \mathrm{~m}$ potassium chloride, stirred intermittently for $30 \mathrm{~min}$ at room temperature and filtered using whatman no. 1 filter paper. The filtrate contained soluble proteins and non-protein nitrogen while the residue contained insoluble proteins. To the filtrate was added $10 \mathrm{ml}$ of $2 \%$ tricholoroacetic acid (TCA), stirred intermittently for $30 \mathrm{~min}$. at room temperature and filtered again. The filtrate contained non-protein nitrogen while the residue contained soluble proteins. All three fractions were subjected to micro-kjeldahl digestion and distillation methods and the percent soluble, insoluble and non - protein nitrogen were calculated.

Total pigment: Total (as acid haematin) pigments were determined according to the method of Hornsey (1956). The optical density of the filtrate was determined at 640 $\mathrm{nm}$ and total pigment calculated as: Total Pigment $(\mathrm{ppm})=$ absobance $($ at $640 \mathrm{~nm}) \times 680$

\section{Sensory Evaluation}

Twenty five persons were ranked according to their ability to make correct judgements using triangular tests with cooked meat samples as test materials. Twenty judges were finally selected from those scoring $60 \%$ and above correct judgements in about 10 trials. During evaluation, about 80 pieces of cooked meat measuring about $2 \mathrm{~cm}^{3}$ or less were placed on flat white enamél plate. 18 such plates were used to correspond to the 3 cooking regimes for the 3 breeds and 2 muscle types. The plates were placed at the sensory evaluation boots and labelled in such a way as to prevent disclosing the identity of the samples. Judges moved to the samples one at a time. Each judge evaluated the samples on a seven-point rating of Excellent (7), Very good (6), Good (5), Medium (4), Poor (3), Very poor (2) and unacceptable (1). Parameters evaluated were colour, texture, juiciness, flavour, tenderness and general acceptability. 


\section{MEAT QUALITY CHARACTERISTICS}

\section{Statistical Analysis:}

Data were anlaysed by analysis of variance using a split-plot model (Gomez and Gomez, 1984) and when differences were significant, Duncan's new multiple range test (Duncan, 1975) was used to separate means.

\section{RESULTS AND DISCUSSION}

Yariations Due to Chemical Composition:

Data on Table 1 show that no significant difference $(\mathbf{P}>0.05)$ in moisture content could be observed between YM and YN bulls or between LD and PM muscles of these breeds. However, meat from YM bulls contained significantly $(\mathrm{P}<0.05)$ lower fat $(1.74 \pm 0.28 \%)$ compared to $\mathrm{YN}(2.48 \pm 0.43 \%)$ while LD muscles contained higher fat $(3.04 \pm 0.13 \%)$ compared to PM muscles $(1.17 \pm 0.22 \%)$. Since both breeds were of the same age range and were managed similarly in the same farm, this result suggests that $\mathrm{YN}$ bulls accumulate intramuscular fat (marbling faster than YM bulls. Callow (1962) reported similar variation in intramuscular fat of Herford and Friesian breeds of cattle and between their LD and PM muscles. When compared to the meat from more mature SG bulls, it is scen that the inature bulls contained lower amount of water $(69: 96 \pm 0.53 \%)$ but higher amount of intramuscular fat $(10.23 \pm 0.31 \%)$ compared to YN and YM bulls. The LD muscles of the mature bulls also contained lower proportions of water but higher percent fat compared to PM muscles. These results support the long known inverse relationship between fat and water in tissues of meat animals and that fat content increases while water content decreases as animals grow older (Lawrie, 1961, Berg and Butterfield, 1976).

Although variations in total ash and nitrogen contents were not significantly different $(P>0.05)$ between $L D$ and $P M$ muscles, or between YM and YN or between the mature and young bulls, it is however observable that ash and total nitrogen contents or mature bulls were lower than those of YM and YN bulls - suggesting age differences. When nitrogen was partitioned into insoluble, soluble and non-protein nitrogen, it appeared
OF NDAMA, MLTURU AND GUDALI that $Y M$ contained lower insoluble proteins $(11.54 \pm 0.50 \%)$ and consequently higher soluble protein $(76.48 \pm 0.42 \%)$ compared to YN $\quad(17.57+0.1 \%$ and $70.56 \pm 0.09 \%$ respectivley). However, muscle differences were not the same for the two breeds with respect to protein solubility. While LD and PM muscles of YM were similar, the LD was significantly different $(P<0.05)$ from $P M$ in YN (Table 1). Meat from mature bulls also contained higher insoluble proteins and non-protein nitrogen than those from YM and YN bulls. Variations in protien solubility are known to depend on the quantities and nature of connective tissue proteins present. These change with age - becoming more reticularized and polymerised as the animal grows older (Boccurd et al., 1979..

The degree of intra-and inter-muscular crosslinkages between the polypeptide chains in collagen has also been found to increase with increasing animal age (Lawrie, 1991) and this is associated with decreasing solubility (Sharp, 1963). The lower proportion of non-protein nitrogen in the muscles of the young bulls compared $(\mathrm{P}>0.05)$ to the mature bulls suggest that these are rapidly utilized in muscle synthesis in the young bulls. As Lawrie (1961) explained, non-protein nitrogen attains its characteristic adult value from 12 months of age. The young bulls used in this study were slaughtered at an average age of 11 months.

Total colour pigments varied significantly $(\mathrm{P}<0.05)$ between YM and $\mathrm{YN}$ breeds as well as between LD and PM muscles of these breeds. YM meat contained higher total pigments $(138.36 \pm 0.52 \mathrm{ppm})$ than $\mathrm{YN}$ meat $(123.42 \pm 0.30 \mathrm{ppm})$ while LD muscles of both breeds had lower total pigment compared to PM muscles. These differences in myoglobin contents are assumed to be due to differences in levels of activity of different muscles. Those muscles or breeds which are more exercised have higher muscle pigments (Lawrie, 1991). It is also seen from Table 1 that mature bulls contained higher muscle pigments than $\mathrm{YN}$ or YM bulls supporting the conclusion of Boccard et al (1979) who observed increase in colour pigments with increase in chronological 


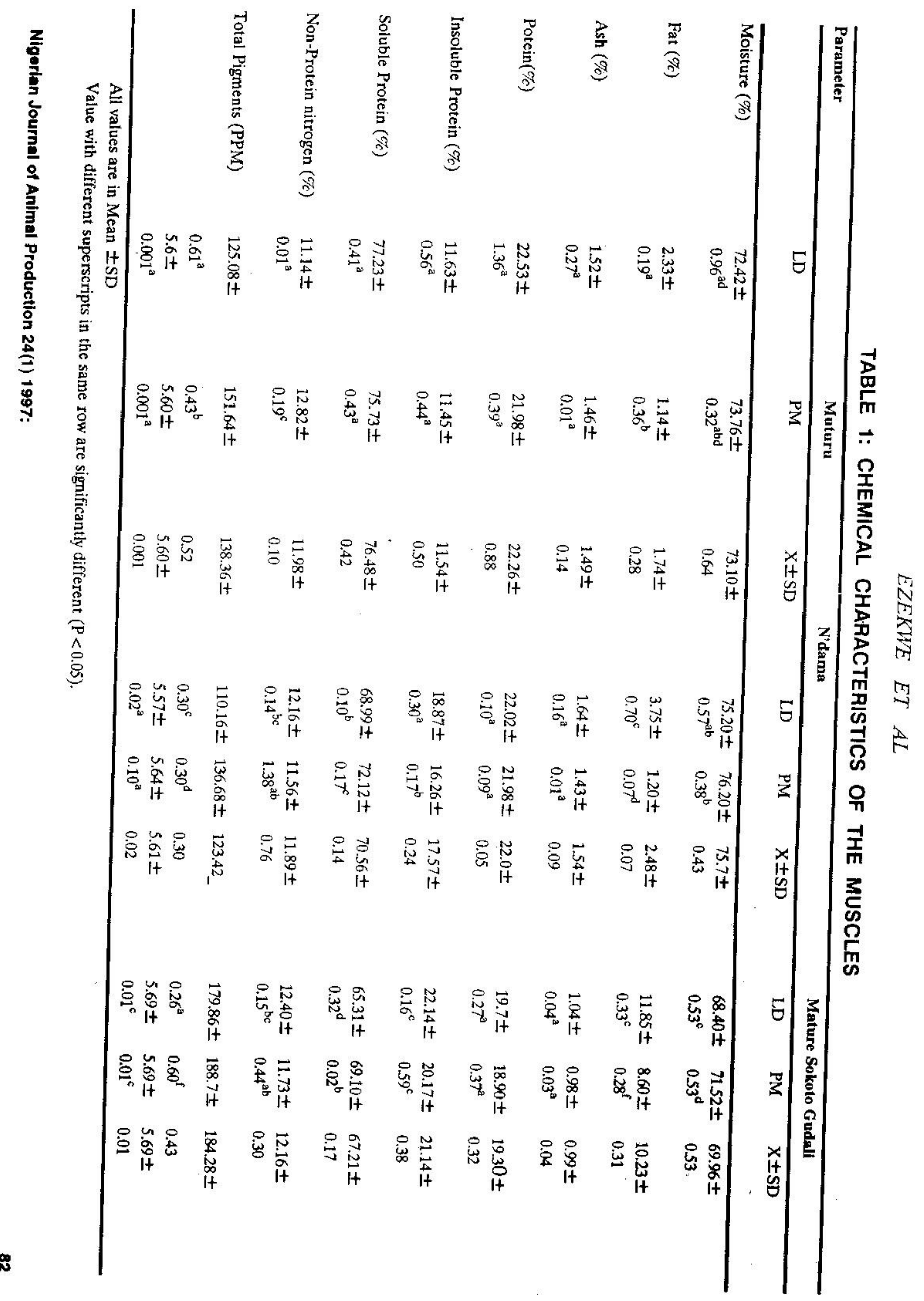




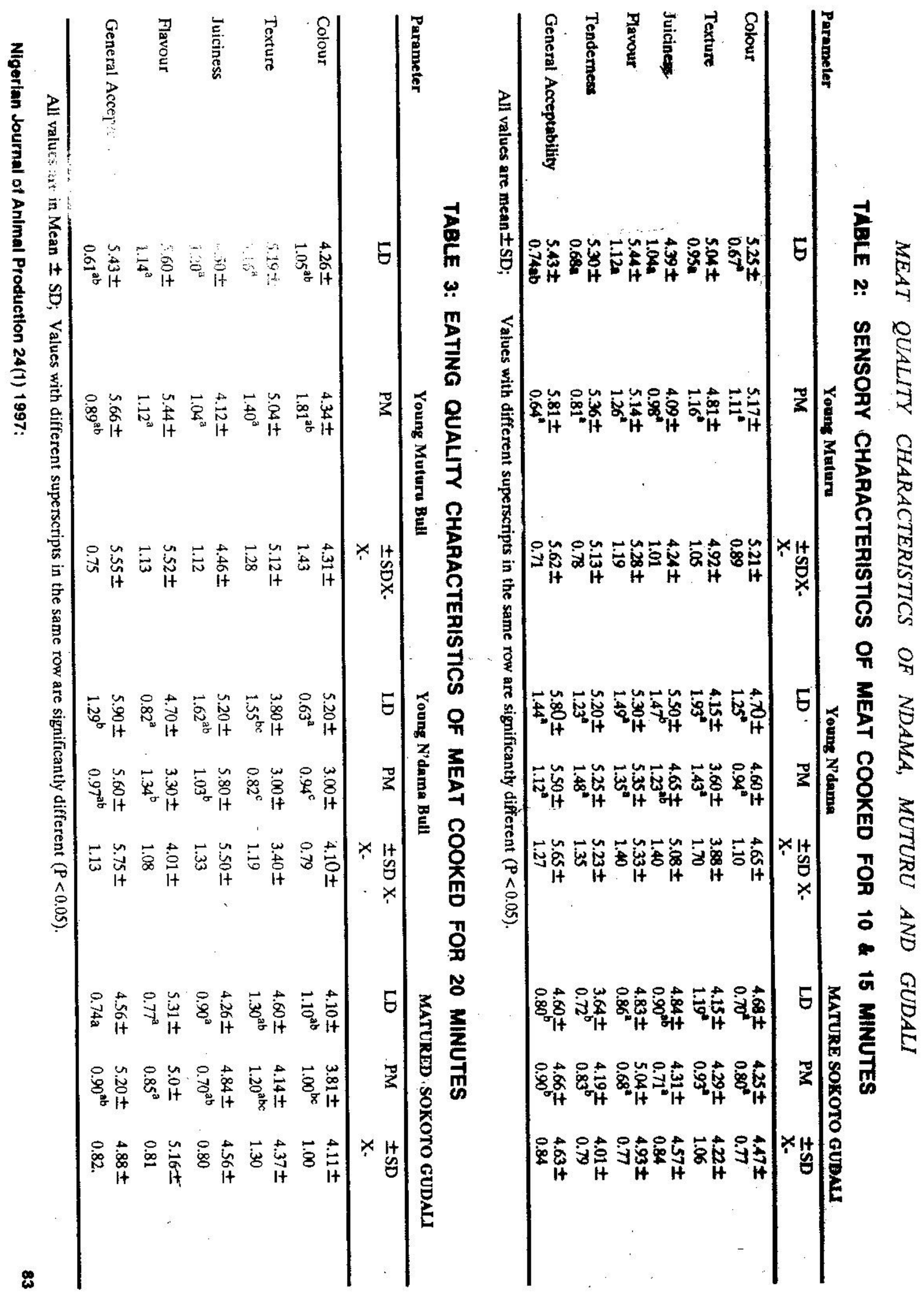


age of Afrikaner and Fresland breeds of cattle. $\mathrm{pH}$ of the sample also varied with maturity and probably influenced total pigment contents ( $r$ $=0.91$ ) such that muscles with high ultimate pH had higher pigment contents. Bouten et al (1978) observed similar effect of age on $\mathrm{pH}$ while Scaife (1955) reported positive relationship of $\mathrm{pH}$ to total pigment contents of muscles.

\section{Sensory Characteristics of The Cooked Meat}

Table 2 summarises the sensory characteristics of the meat cooked for 10 and 15 min. It was found that there were differences $(P>0.05)$ between samples cooked for $10 \mathrm{~min}$ and $15 \mathrm{~min}$ in all parameters evaluated, thus in Table 2 these two results were combined. It is readily seen that all samples were acceptable but significant difference in colour, texture and flavour were not observed $(P>0.05)$ between brceds or muscles of maturity after 10 and $15 \mathrm{~min}$ cooking. Apparently, the length of cooking time was not sufficient to reveal significant difference in these parameters (Locker et al., 1977; Davey and Niederer, 1977). But differences were observed in tenderness after 10 and 15 min cooking and it is shown that mature bulls were significantly less tender $(4.01 \pm 0.79)$ compared to YM $(5.13 \pm 078)$ and YN (5.23 \pm 1.35$)$ bulls. The observed differences in tenderness appeared to be sufficient to enable panelists detect significant differences in general acceptability. $Y M$ and YN bulls were more acceptable than mature bulls after 10 and 15 min. cooking. After cooking for $20 \mathrm{~min}$. (Table 3,), judges could show that significant differences $(P<0.05)$ exist between meat samples in colour, texture, flavour, juiciness, tenderness and general acceptability. It is probable that juiciness, flavour and tenderness influence eating quality of the cooked meat product because those muscles which scored high in these parameters also scored high in general acceptability.

The results show that cooked meat from young (11 months) Muturu and N'dama can be of acceptable eating quality. Similar conclusions on other breeds of cattle have

\section{ET $A L$}

been reached by various workers (Field, 1971, Hunsley et al., 1971; Ntunde et al., 1977; Riley et al., 1986). After cooking for 20 min meat from YM cattle possessed more desirable flavour and tenderness than $\mathrm{YN}$ which was better in juiciness presumably due to higher moisture content of $\mathrm{YN}$ muscles $(74.7 \pm 0.43$ vs $73.1 \pm 0.64)$.

\section{ACKNOWLEDGEMENT}

Ezekwe, A.G. is very grateful to the International Foundation for Science (IFS), Sweden which sponsored the larger research with grant No. B/1108-1. The present research was an offshoot of that bigger research.

\section{REFERENCES}

AOAC (1990). Official Methods of Analysis. 15th ed. Association of Official Analytical Chemists, Washington.

BERG, R.T. AND BUTTERFIELD, R.M. (1976). New concepts of cattle growth. Sydney University Press. Australia

BOCCARD, R.L., NAUDE, R.T., CRONJE, D.E., SMITH M.C., VENTER, H.J. AND RASSOUW, E.J. (1979). The influence of age, sex and breed of cattle on their muscle characteristic. Meat science 3: 261 - 280.

BOUTEN, P.E., FORD, A.L., HARRIS, P.V., SHORTHOUSE, W.R., RATCLIFF, D. AND MORGAN, J.H. (1978). The influence of animal age on the tenderness of beef: Muscle differences. Meat Sci. 2, 301 -312.

CALLOW, E.H. (1962). Comparative study of meat. VIII. The percentage of fat in the fatty and muscular tissues of steers and the iodine number of the extrated fat as affected by breed and level of nutrition. J. Agric. Sci., 58: 295-307.

DAVEY, C.L. AND NIEDERER, A.F. (1977). Cooking tenderising in beef. Meat Sci., 1: 271-276.

DUNCAN, D.B. (1975). Tests and intervals suggested by the data, Biometrics, 31: 339 359

FIELD, R.A. (1971). Effects of castration on meat quality and quantity. J. Anim. Sci., 32: 
MEAT QUALITY CHARACTERISTICS 849 - 858.

GOMEZ, K.A. AND GOMEZ, A.A. (1984). Statistical procedures for agricultural research. 2nd ed. A Wiley and Sons Publ. New York.

HORNSEY, H.C. (1956). The colour of cooked cured pork. I. Estimation of nitric oxide haemopigments, J. Sci. Food Agric. 1: 534 540.

HUNSLEY, R.E., VETTER, R.L., KEINE, E.A. and BURROUGH, W. (1971). Effects of age and sex on quality, tenderness and collagen contents of bovine longissimus muscle. J. Anim. Sci. 33: 933 - 938

LAWRIE, R.A. (1961). Studies on the muscles of meat animals. I. Differences on the composition of beef Longissimus dorsi muscles determmined by age and anatomical location. J. Agric Sci. 56: 249 - 256.

LAWRIE, R.A., (1991). Meat Science. 5th Ed. Pergammon Press London.
OF NDAMA, MUTURU AND GUDALI

LOCKER, R.H., DAINES, G.J., CARSE, W.A AND LEET N.G., (1977). Meat tenderness and gap filament. Meat Sci. 1: 87 - 104.

NTUNDE, B.N., OSBORNE, W.R. AND ASHTON, G.C. (1977). Responses on meat characteristics of Holstein-Friesian males to castrate and diet.. Canadian J. Anim. Sci. 57: 449 - 458.

RILEY, R.R., SMITH, G.G., RUSS, H.R., SAVEL, J.W., LUNE, C.R, AND CATWRITHT, T.C (1986). Chronological age and breed type effects on carcass characteristics and palatability of bull beef. Meat Sci. 17: 187 - 198.

SCIFE, J.F. (1955). Variation in ultimate PH within pig muscle. J. Sci. Food Agric. 6, 467 471.

SHARP, J.G. (1963). Aseptic autolysis in rabbit and bovine muscles during storage at $37^{\circ} \mathrm{C} . \mathrm{J}$. Sci. Food Agric. 14, 468 - 479. 